Evidence Report. NIH Publication No. 98-4083. Washington DC: US Government Press, 1998. http://www.nhlbi.nih. gov/guidelines/obesity/ob_gdlns.pdf (7 March 2012, date last accessed).

8. Rona RJ, Sundin J, Wood P, Fear NT. Agreement between body mass index, waist circumference and skin-fold thickness in the United Kingdom Army. Ann Hum Biol 2011;38:257-264.
9. Romero-Corral A, Somers VK, Sierra-Johnson J et al. Normal weight obesity: a risk factor for cardiometabolic dysregulation and cardiovascular mortality. Eur Heart $\mathcal{f}$ 2010;31:737-746.

10. Flegal KM. Waist circumference of healthy men and women in the United States. Int $\mathcal{F}$ Obes (Lond) 2007;31:1134-1139.

\title{
Learning from the Vikings: Hávamál and occupational rehabilitation
}

Although the pioneering work of Bernardo Ramazzini is often cited as the origin of occupational health, an awareness of some aspects of occupational illness dates back to classical times [1]. Hippocrates described lead poisoning, and Pliny was aware of the poisonous nature of sulphur, mercury and lead.

Our first historical insight into a different aspect of occupational health arises from a surprising source, one of the first of the Viking sagas. Viking culture suffers unfairly from images of savage warriors with horned helmets intent on rape and pillage wherever their beautiful ships bore them. One might imagine that their addition to the lore of medicine would be more likely to arise in emergency medicine and trauma orthopaedics.

Yet as visitors to Dublin and York will know, the Vikings led remarkably sophisticated lives within a highly organized and structured culture. From one of their most ancient of Norse poetic sagas, Hávamál [2], we find a wisdom that points to one of the key aspects of occupational health, how to overcome the hurdle of diagnosis as catastrophe and occupational rehabilitation to the workplace.

This extended and often very droll poem was handed down in oral tradition, purportedly from the Norse god Odin-what better authority could we ask for? - and is a sequence of pithy advice and wise counsels. In addition to guidance on the perils of drunkenness, visitors out-staying their welcome and the virtues of silence, a number of stanzas deal with illness.

After a nod to preventive medicine-'These things are thought the best:/.. ..,/Good health with the gift to keep it,/And a life that avoids vice'-we are reassured by the importance of family support and what remains in illness: 'Not all sick men are utterly wretched:/Some are blessed with sons,/Some with friends,/some with riches,/Some with worthy works'. The contrast with the alternative is always present: 'It is always better to be alive,/The living can keep a cow./Fire, I saw, warming a wealthy man,/With a cold corpse at his door'.

But the true spark lies in the promotion of adaptation of acquired disability to certain types of occupation: 'The halt can manage a horse,/the handless a flock,/The deaf be a doughty fighter'. These wonderful images should reassure us that the mission of occupational medicine builds on a tradition that is considerably older than we may have imagined.

And although we would never be so blunt in practice, the steely truth of the stanza's final line-- 'To be blind is better than to burn on a pyre/There is nothing the dead can do'-is an unspoken motivation that we all too rarely articulate.

Desmond O'Neill

e-mail:doneill@tcd.ie

\section{References}

1. Abrams HK. A short history of occupational health. $\mathcal{f}$ Public Health Policy 2001;22:34-80.

2. Anonymous. Hávamál circa 800-900AD. 